\title{
Future Perspectives in the Treatment of Heart Failure: From Cell Transplantation to Cardiac Regeneration
}

\author{
Felipe Prósper, Jesús Herreros, and Joaquín Barba \\ Servicio de Hematología y Área de Terapia Celular, Departamento de Cardiología y Cirugía Cardiovascular, \\ Clínica Universitaria, Universidad de Navarra, Pamplona, Spain.
}

\begin{abstract}
The last few years have witnessed growing interest in regenerative therapy for the failing heart by cell transplantation. Although initial studies with skeletal myoblasts are more than 10 years old, the potential of bone marrow-derived cells has led to a flurry of experimental studies generating generally positive but occasionally contradictory results. This has given rise on not a few occasions to conflicting viewpoints regarding the ethics of initiating clinical trials. We feel it is appropriate to offer a critical view of the use of stem cells for heart failure. Perhaps the thorniest question to answer at this time is whether clinical trials are justified or not in the light of current knowledge, or whether we should acquire deeper knowledge of the possible efficacy and safety of this type of treatment, and of the mechanisms that account for its efficacy, before we so much as initiate studies in humans. We feel there is now sufficient evidence to justify the performance of clinical trials despite the undoubtedly numerous questions that remain to be answered with experimental studies in animals.
\end{abstract}

Key words: Stem cells. Myoblasts. Cardiac regeneration. Plasticity.

Full Spanish text available at: www.revespcardiol.org

\section{Perspectivas futuras de tratamiento en la insuficiencia cardíaca: del trasplante de células a la regeneración cardíaca}

En los últimos años hemos asistido a un interés creciente por el tratamiento de la insuficiencia cardíaca mediante el trasplante de células madre. Mientras que los estudios con células madre de músculo (mioblastos) se iniciaron hace más de 10 años, la posibilidad de que las células madre de la médula ósea tengan un enorme potencial de diferenciación y proliferación ha estimulado la investigación con otros tipos de células madre. Estos estudios experimentales han demostrado, en no pocas ocasiones, resultados contradictorios, lo que ha llevado a posturas enfrentadas en cuanto a la ética de iniciar estudios clínicos. Creemos que es adecuado tratar de ofrecer una visión crítica respecto a la utilización de las células madre en la insuficiencia cardíaca. Quizá la pregunta más difícil de contestar en este momento es si la realización de ensayos clínicos está justificada o no a la luz de los conocimientos actuales, o si por el contrario debemos adquirir un conocimiento mucho más preciso de la posible eficacia de este tipo de tratamiento y de los mecanismos que justifican esta eficacia, antes de siquiera iniciar los estudios en humanos. En nuestra opinión, hay suficientes evidencias que justifican el desarrollo de ensayos clínicos a pesar de que, sin duda, existen muchos interrogantes que debemos resolver mediante estudios experimentales en animales.

Palabras clave: Células madre. Mioblastos. Regeneración cardíaca. Versatilidad.

promising developments in the treatment of a substantial number of patients affected by illnesses for which there is currently little or no hope of cure. The potential use of cell therapy in heart failure is clearly attractive due to the high incidence and prevalence of this disease and the absence of a cure other than heart transplantation. ${ }^{1}$ Over the last 10 years, cells derived from different sources have been grafted into damaged regions of the heart and shown they can produce functional benefits. Obviously, the greater the expectations a specific treatment raises, the more prudent we should be in its application and in evaluating results; we must do our utmost to uphold scientific crite-
Research part-financed by the Spanish Ministry of Science and Technology (SAF 2002-04574-C02), European Regional Development Fund ERDF (INTERREG IIIA), and Universidad de Navarra (PIUNA)

Correspondence: Dr. F. Prósper.

Servicio de Hematología y Área de Terapia Celular.

Avda. Pío XII, 36. 31008 Pamplona. España.

Correo electrónico: fprosper@unav.es 
ria and thus avoid adverse results that might compromise the future of the new treatment. A recent example can be seen in the use of gene therapy., ${ }^{2,3}$

Whatever the case may be, we believe experimental data and results from the first studies in patients justify the development of well-designed, rigorously controlled clinical trials in the field of cell therapy for heart failure. We recognize that opinion is divided over this issue, from the most optimistic perspectives to significantly more restrictive views. ${ }^{4}$ Without doubt, there are many unknown factors and limitations that should be researched and resolved prior to cell therapy becoming part of the arsenal of therapies in heart failure, but we do not think it justified to demand answers to all our questions prior to initiating clinical trials.

In the following pages we try to identify some of the obstacles and the most relevant questions about the application of cell therapy in cardiology. These include the issue of cell types, mechanisms, delivery, possible secondary effects and indications. In spite of numerous existing studies, most of these questions have yet to be answered clearly. One of the benefits of the development of regenerative medicine is the stimulus it provides to new diagnostic techniques to evaluate function, viability, perfusion, etc. For lack of space, we will not enter into these aspects here, nor will we discuss more specific issues such as optimal cell delivery procedures or indications for cell therapy, as we believe it somewhat premature to establish indications for a treatment still under investigation. There are excellent recent reviews which deal with some of these issues. ${ }^{5}$

\section{CARDIAC REGENERATION WITH STEM CELLS: WHICH TYPE OF CELL IS IDEAL?}

Although the alternatives theoretically include the use of cardiomyocytes, embryonic stem cells, cardiac stem cells, skeletal myoblasts, or bone marrow-derived stem cells, we will focus principally on those cell types currently available for clinical use: bone marrow-derived stem cells and skeletal myoblasts.

\section{Skeletal Myoblasts}

There are numerous reasons why satellite cells or myoblasts were the first type of stem cell used in myocardial regeneration: their capacity to proliferate in vitro; their program of development limited to muscular tissue and, thus, with minimal risk of developing tumors; the possibility of obtaining autologous cells; and their great resistance to ischemia. Numerous experimental studies use skeletal myoblasts in models of acute and chronic infarction in rodents and larger animals such as pigs or sheep. ${ }^{6}$ These studies have led us to a series of conclusions that constitute the justification for the clinical trials carried out to date and that we try to summarize below. Skeletal myoblasts implanted in animals with myocardial infarction are capable of engraftment both in and around the infarcted area and differentiate into multinuclear myotubes. Some studies detected implanted cells up to 12 months post-trasplantation ${ }^{7}$ but in most cases follow-up was limited to 4-12 weeks meaning that the long-term survival of implanted cells is still unclear. On the other hand, the percentage of cells capable of engraftment in the myocardium, even a few weeks after implantation, is extremely low, ranging between $1 \%$ and $6 \%{ }^{8}$

Most experimental studies show myoblast transplantation contributes significantly to improved cardiac function-principally systolic function (ejection fraction) but in some cases diastolic function too. In general, improvement is proportional to the number of engrafted myoblasts ${ }^{9,10}$ and is maintained over time. Although some initial studies suggested skeletal myoblasts were capable of acquiring cardiac musclelike properties and even of transdifferentiating and establishing electromechanical connections, ${ }^{11}$ current evidence indicates myoblast transdifferentiation does not occur and, moreover, that skeletal muscle fibers cannot mechanically couple with cardiomyocytes or establish dense unions. ${ }^{12}$ However, it also seems clear that skeletal muscle fibers are capable of acquiring certain characteristics of cardiac muscle cells and expressing slow and fast contraction muscle fibers which favor their resistance to muscle fatigue (Figure 1).

At this point it is worth commenting on a recently published study by Reinecke et $\mathrm{al}^{13}$ which shows that in a mouse model, skeletal myoblasts are capable of fusion with cardiac muscle cells in vivo. If these results can be reproduced by other groups, they would justify the use of skeletal myoblasts as a strategy of cardiac regeneration demonstrating that at least one possible mechanism would be fusion between implanted cells and cardiomyocytes resident in the heart.

To date, 5 phase I clinical studies with autologous skeletal myoblasts in patients with cardiac heart disease have been published. Results obtained from the first patient to receive direct intracardiac administration of myoblasts were published by Menasche et al ${ }^{14}$ who later described results obtained in a phase I trial with a total of 10 patients. ${ }^{15}$ These patients had a history of myocardial infarction and indication for coronary revascularization surgery. At surgery, they received direct intramyocardial injection of skeletal myoblasts previously obtained from the patients themselves and cultivated in vitro for 14-16 days. The results show that revascularization and myoblast transplantation associated with a significantly improved myocardial function (improved systolic volume and increased ventricular ejection fraction) together with signs of increased myocardial viability shown in positron emission tomography (PET) (Figure 2). The most important secondary effect found 
Fig. 1. Human myoblast culture. Upper panel: flow cytometric identification of skeletal myoblasts by expression of CD56 antigen and non-expression of CD45 antigen. Skeletal myoblasts are positive for desmin. Lower panel: immunofluorescence analysis shows myoblasts express transcript factors associated with muscular differentiation (Myo-D) and desmin.

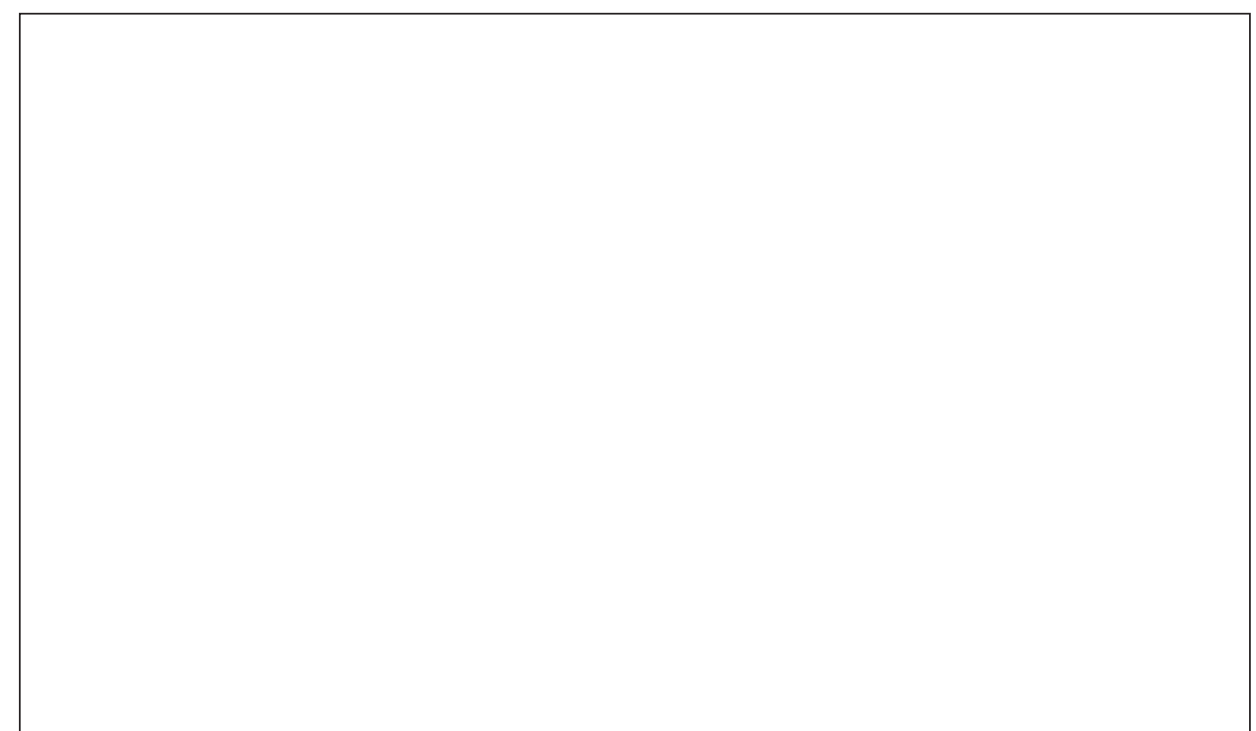

was high incidence of ventricular arrhythmias which in 4 patients required implantation of a ventricular defibrillator. Whether in the form of summaries (Dib's phase I studies with scaled doses of myoblasts and Siminiak's group ${ }^{16}$ ), or articles, ${ }^{8,17,18}$ results of 6 studies of cardiac regeneration with skeletal myoblasts have been published. These involved 3 different clinical situations: intramyocardial delivery associated with aortocoronary revascularization surgery ${ }^{15-17}$; percutaneous transendocardial delivery ${ }^{18}$; or delivery during implantation of a ventricular assistance system. ${ }^{18}$

What can we deduce from the results of these studies? In fact, they confirm some of the findings described in experimental models. Firstly, they show the feasibility of the procedure. At least 2 studies show that skeletal myoblasts are anatomically capable of engraftment in the heart. ${ }^{8,19}$ On the other hand, a constant factor in all of them is the production of functional improvement with an increase in ventricular ejection fraction. However, in most of the studies cell treatment is associated with revascularization surgery making it currently impossible to determine whether myoblast transplantation alone contributes directly to functional improvement. It is worth mentioning that recent research indicates that at best revascularization surgery makes a very limited contribution to improving ventricular function. Consequently, this would support the idea that myoblast transplantation is efficient even though the mechanism that induces the improvement is still unknown. ${ }^{20}$ In any case, only by carrying out randomized studies with and without myoblast delivery together with revascularization surgery will we be able to determine definitively the efficacy of this strategy. At the time of writing, at least 3 randomized studies are under way in France, Spain, and the US. Percutaneous delivery will also enable us to determine the efficacy of myoblast treatment, as suggested by the only study published to date. ${ }^{18}$

One of the most controversial aspects of the use of myoblasts, which was not, in fact, anticipated by the experimental studies, has been the appearance of cardiac arrhythmias. ${ }^{8,15}$ Although different hypotheses exist, the mechanism producing these arrhythmias is unknown and the presence of arrhythmias has not been constant in all studies. ${ }^{17}$ Although it is relevant, we cannot currently confirm that myoblast transplantation induces cardiac arrhythmias. The results of new clinical and experimental trials should determine whether myoblasts are arrhythmogenic and establish the possible mechanism.

One fundamental question is: what is the mechanism through which myoblasts can contribute to improved cardiac function? Several hypotheses exist but none of them is certain. Skeletal myoblasts may facilitate cardiac muscle elasticity, limiting the extent of infarction and impeding ventricular remodeling. This would be an exclusively mechanical effect depending on the formation of a structure that would support the muscle, but with a purely passive role. A second mechanism might depend on the liberation of different substances and growth factors by myoblasts. These substances would permit the reorganization of the extracellular matrix (secretion of metalloprotease), ${ }^{21}$ induction of angiogenesis (endothelial vascular growth factor) and even mobilization and nesting of stem cells derived from other tissues. ${ }^{22}$ Although much evidence exists against the integration of myoblasts with cardiomyocytes, recent studies that show fusion between myoblasts and cardiomyocytes would support the argument that myoblasts might act because they would directly benefit systolic function by incorporating into cardiac muscle. In our opinion, briefly, this hypothesis appears somewhat unlikely. Various mechanisms may 


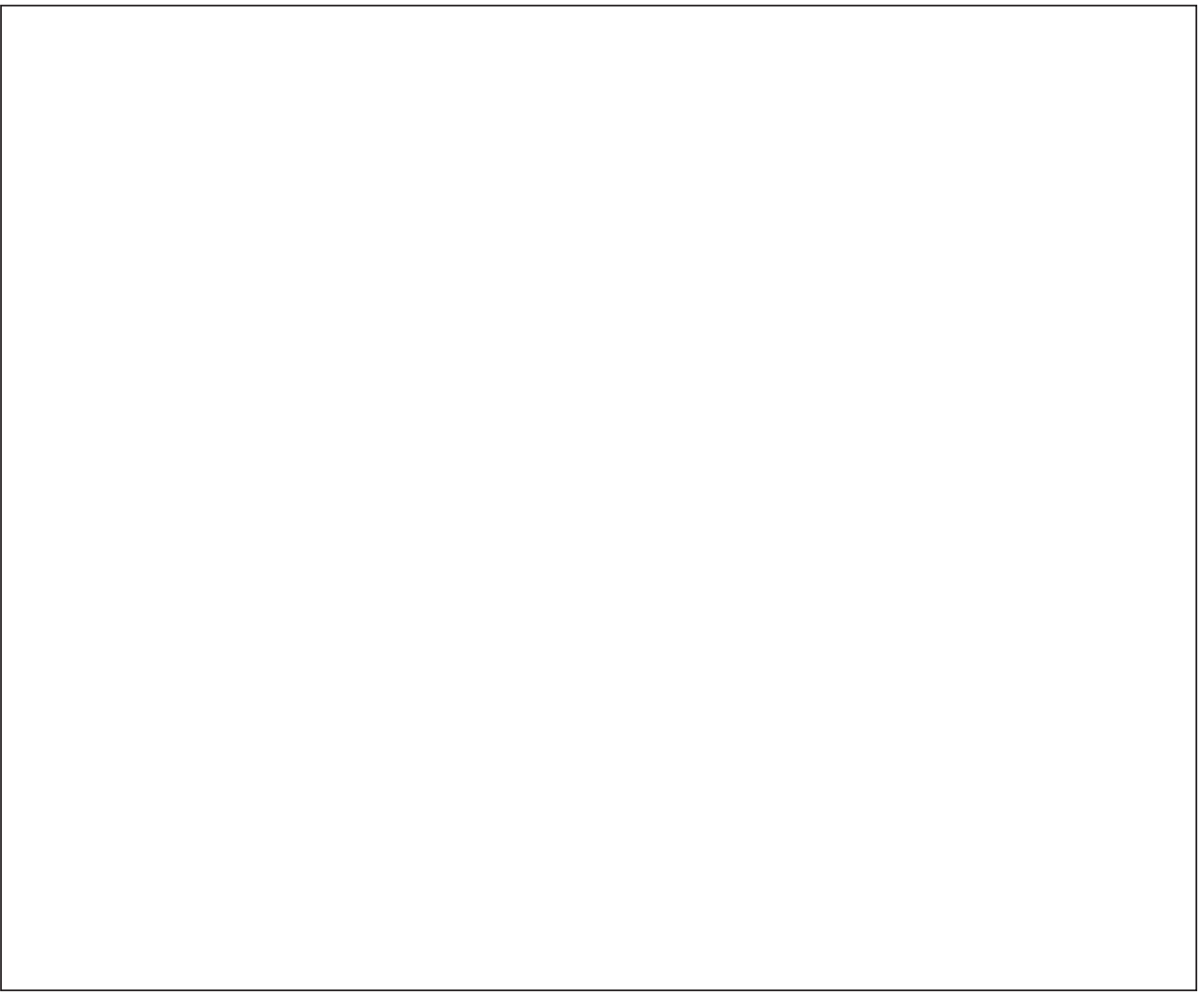

Fig. 2. F-18-fluorodeoxyglucose (FDG) positron emission tomography (PET) imaging. The lefthand panel corresponds to the PET image in a post-myocardial infarction patient. The arrowheads point to a deficit of FDG uptake that would indicate an image of necrosis. At 3 months after revascularization surgery and autologous myoblasts implantation, a highly significant improvement in FDG uptake can be seen which would indicate greater viability. The right-hand panel corresponds to a patient who underwent revascularization surgery without cell transplantation and in whom improved tissue viability cannot be seen.

contribute to its efficacy and in acute or chronic situations the mechanisms may differ. In acute infarction, action on ventricular modeling might be more efficient; in chronic infarction a passive mechanical mechanism might offer advantages. Independently of the nature of the mechanism, there can be no doubt that animal studies together with the preliminary clinical evidence justify continuing clinical trials that will permit us to determine the therapeutic efficacy of this treatment.

\section{Bone Marrow-Derived Stem Cells}

In this case the panorama is more complicated. Different populations of bone marrow-derived stem cells are capable, at least in vitro, of differentiating into cardiac muscle or endothelial cells and contributing to contractile function, and to angiogenesis and vasculogenesis. Bone marrow is a complex microenvironment. In contrast to what has happened in the case of skeletal myoblasts, where studies in patients have begun after several years of experimentation, the clinical application of bone marrow has begun with less preclinical evidence of efficacy. This does not mean there is no rational basis for their use but, simply, that their efficacy in animal models has been documented to a lesser extent.

We can divide the studies of cardiac regeneration with bone marrow-derived cells into those with non- selected populations and those with purified stem cells (endothelial or hematopoietic) and those that use mesenchymal cells.

To date, most clinical studies with bone marrowderived stem cells have used non-selected cells: that is, a cell pool that includes stem cells and differentiated cells. Justification for this is easily understood: the procedure is simple (to carry out a selection of cells using a density gradient is within the scope of any laboratory), cheap and not subject to the regulatory procedures required for in vitro cell manipulation. Theoretically, by using all the bone marrow cell population we avoid losing cells that are potentially useful, whether for their capacity to differentiate into cardiomyocytes or endothelial cells or liberate substances that favor cellular regeneration. On the contrary, we introduce cell types capable of inducing adverse effects by liberating inflammatory substances. In general, experimental studies with mononuclear bone marrow-derived cells offer contradictory results. Some research indicates an improvement in vascularization and cardiac function, ${ }^{23,24}$ whereas other studies show no benefit at all. ${ }^{25,26}$ The heterogeneity of the implanted cells makes it difficult to compare these studies. Clinically, mononuclear bone marrow- or peripheral blood-derived cells have been delivered by intracoronary injection in patients with acute myocardial infarction undergoing angioplasty ${ }^{27-29}$ or with electromechanical guidance in patients with chronic 
ischemia. ${ }^{30-32}$ These studies aimed to demonstrate the feasibility of the treatment and its possible efficacy in terms of improved cardiac function, perfusion and tissue viability. In some of the studies, results of cell treatment have been compared with control groups receiving similar treatment but without cell transplantation. However, these were not randomized clinical trials $^{27,30}$ and on the whole, results suggest the treatment is accompanied by improved cardiac function and increased myocardial perfusion. The most widely accepted hypothesis is that mononuclear cells increase vascularization and tissue angiogenesis although this has certainly not been demonstrated in experimental models or in humans. In a recent comparative study, patients with acute infarction and stent implantation were subsequently randomized in 3 groups: patients who received mononuclear peripheral blood cells mobilized with granulocyte colony stimulating factor (GCSF); patients who received G-CSF; and controls. The high incidence of restenosis in the patients with GCSF has brought the trial to a halt and raised the issue of the possible secondary effects associated with this type of treatment as well as adding a certain degree of skepticism to cell therapy. ${ }^{28}$

A second option consists of using stem cell populations with a potential demonstrated at least in in vitro models. The phenotype of bone marrow-derived hematopoietic stem cells in the rat is perfectly defined and the different stem cell populations have been characterized in detail. However, for obvious reasons, reconstitution studies in humans have not been carried out so bone marrow-derived stem cell populations are not as well defined. However, markers, such as the expression of CD34 and AC133 antigens, are associated with hematopoietic and endothelial stem cells.

The use of hematopoietic stem cells is founded on the existence of studies in animal models, principally rats and mice, which show the capacity of different stem cell populations to differentiate into endothelial cells and even cardiomyocytes, contributing to improved cardiac function. We think that because recent studies directly and explicitly question these initial experiments, it is worth dedicating a few lines to debating them prior to describing the clinical situation.

The first studies of cardiac regeneration with hematopoietic stem cells used side population cells in a model of ischemia in the mouse ${ }^{33}$ or intravenously delivered CD34 cells in a model of infarction. ${ }^{34}$ Both studies demonstrated hematopoietic stem cells were capable of contributing to myocardial regeneration through their capacity for favoring angiogenesis and vasculogenesis and, possibly, differentiating into cardiomyocytes. However, the most spectacular results were reported by Orlic et $\mathrm{al}^{35}$ who, using a model of acute infarction in mice and administering Lin-c-kit+ hematopoietic stem cells (purified population of hematopoietic stem cells), demonstrated these cells were capable of differentiating in vivo into cardiomyocytes and endothelial cells, contributing to improved myocardial contractility and the survival of the animals. Controversy has arisen out of 2 recently published reports in Nature that not only question the fact that hematopoietic stem cells differentiate into cardiomyocytes, but directly doubt Orlic et al and indirectly question all evidence of transdifferentiation. ${ }^{36,37}$ While it is true that Orlic et al stimulated the clinical development of cell therapy with stem cells in patients with infarction, it would be unjustified to pretend that the entire scientific base that supports clinical trials in patients with myocardial infarction is to be found in this one study alone. This is not the place for a detailed discussion of these 3 contradictory studies, but we at least want to recall certain specific aspects of the 2 more recent articles. These studies report negative results and, as in all studies with negative findings, we cannot ignore the fact that simply, the model used might not have been adequate. On the other hand, the only conclusion we can reach about these trials is that a determined population of hematopoietic stem cells in mice in a model of acute infarction does not differentiate into cardiomyocytes (except by fusion); we cannot enter into therapeutic inefficiency since one of the studies does not even evaluate it, ${ }^{36}$ and in the other the results suggest slightly improved function in the animals treated with the cells. ${ }^{37}$ Finally, these studies only looked at the capacity of a very specific stem cell population, hematopoietic stem cells, and as other types of stem cells are found in bone marrow, it cannot be concluded that bone marrow-derived stem cells are incapable of myocardial regeneration. In the discussions and conclusions of both articles, the authors question the carrying out of clinical trials. We consider this unjustified and suggest that carefully designed, controlled clinical trials with specific, relevant research questions should be carried out.

A new study, published in 2004, adds a different perspective: using again hematopoietic stem cells and a model of infarction in the mouse it is possible to obtain cardiomyocytes from hematopoietic stem cells but the mechanism is through cellular fusion. ${ }^{38}$ These findings concur with an earlier study. ${ }^{39}$

Intracoronary delivery of endothelial stem cells (also known as endothelial progenitor cells [EPC]) has been used in patients with acute myocardial infarction on the hypothesis that these cells would contribute to improving angiogenesis and recovering hibernating tissue. $^{40}$ The efficacy of bone marrow-derived EPC was compared with peripheral blood-derived cells and a control group. Functional results and PET perfusion study data suggest the efficacy of endothelial stem cells. Among bone marrow-derived stem cells, the population of AC133-positive cells is considered particularly enriched in hemangioblast progenitors, capable of differentiating into endothelial and hematopoie- 
tic cells. The potential of these cells, and the fact that it is technically possible to purify them from human bone marrow or peripheral blood has favored their clinical use, described for the first time in a group of post-infarction patients undergoing coronary revascularization surgery. ${ }^{41}$ Initial results show that a single dose of $10 \times 10^{6} \mathrm{AC} 133$ cells produced an improvement in function and myocardial perfusion. Consequently, the authors have begun a randomized study in which patients where assigned to receive treatment with AC133 cells and surgical revascularization or surgery alone. Preliminary results with the first 20 patients indicate greater functional recovery in the group treated with AC133 cells (personal communication).

Although mesenchymal stem cells have only been used as a strategy of cardiac regeneration in animal models, the cell type is particularly attractive due to its capacity for in vitro differentiation into cardiac muscle cells and because a substantial number of cells can be obtained simply, efficiently and relatively cheaply. Mesenchymal cells can be obtained from various tissues, principally bone marrow and adipose tissue (also known as vascular fraction of the stroma). Both adipose tissue- and bone marrow-derived mesenchymal cells have shown their capacity to differentiate simultaneously in vitro into cardiac muscle cells and endothelial cells, making them especially interesting because they can regenerate the myocardium and contribute to neoangiogenesis and vasculogenesis. ${ }^{42-44}$ Bone marrow-derived mesenchymal cells have been used in experimental models of myocardial infarction in rats and pigs and have shown their capacity to improve cardiac function ${ }^{45}$ and differentiate into cardiac muscle cells. ${ }^{46}$ Mesenchymal cells, genetically modified with a survival factor, have produced substantial improvements in cell survival after implantation in infarcted mice ${ }^{47}$ However, no published clinical studies report the use of mesenchymal cells in patients with myocardial infarction.

\section{CONCLUSIONS}

The fundamental issue of the current controversy is whether adult stem cells (hematopoietic or of another type) are capable of transdifferentiation or whether observations that suggest that this occurs can be explained through other mechanisms, such as cellular fusion, or inclusive this is related to simply incorrect interpretations of experimental results. The detailed discussion of this topic is beyond the objectives of the present article but those readers who are interested are recommended to read recent review articles. ${ }^{48,49} \mathrm{Nev}$ ertheless, we believe it is important to try to transmit a series of ideas that we hope can help readers reach their own conclusions in an area of medicine that is highly emotional and thus be able to interpret many of the published studies more critically:
1. Bone marrow-derived stem cells are not exclusively hematopoietic stem cells. Consequently, generalizations lead to confusion. For example, hematopoietic stem cells may not differentiate into cardiac muscle, but bone marrow-derived AC133 or CD34 cells are undoubtedly not exclusively hematopoietic stem cells as they also include endothelial and even mesenchymal stem cells. In consequence, their capacity for differentiating may be much greater than that of hematopoietic cells.

2. It is not absolutely fundamental that transdifferentiation and functional integration of stem cells into tissue should occur for them to be efficient. Doubtless, this would be ideal, but the fact that it may not occur does not exclude the possibility that their use may contribute to therapeutic benefit.

3. Cellular fusion between stem cells and cells resident in the tissue occurs both in vitro and in vivo. However, cellular fusion may be a part of cellular repair, as in skeletal muscle where damaged tissue recuperates through the proliferation of satellite cells and their later fusion on transforming into myofibers. In the specific case of the heart, it is worth remembering that cardiac muscle is formed by connected and, therefore, "fusioned" cells.

4. At least in vitro, it has been clearly demonstrated that it is possible to reprogram cells and induce transdifferentiation. Whether these exist in vivo and the extent to which they may exist, have yet to be proven.

5. If knowing the mechanisms by which a specific treatment is efficient prior to applying it is the objective of medicine, we invite our readers to ask themselves for how many treatments currently accepted as efficacious and in daily use, they know all of the mechanisms by which they function and all the possible secondary effects, and even then continue to use them. It would be ideal if we could follow the criteria proposed by $\mathrm{Chien}^{4}$ prior to initiating the clinical application of stem cells, but it would not be realistic or ethical to impede many thousand of patients from benefiting in order to satisfy scientific knowledge (a multitude of examples can be found in the history of medicine). This does not waive our responsibility to carry out strict, objective research that might enable us to clarify the possible mechanisms by which this type of treatment may function ${ }^{50}$.

\section{REFERENCES}

1. Rodríguez-Artalejo F, Banegas Banegas JR, Guallar-Castillon P. Epidemiología de la insuficiencia cardíaca. Rev Esp Cardiol 2004;57:163-70

2. Check E. Cancer fears cast doubts on future of gene therapy. Nature 2003;421:678.

3. Check E. Harmful potential of viral vectors fuels doubts over gene therapy. Nature 2003;423:573-4. 
4. Chien KR. Stem cells: lost in translation. Nature 2004;428:607-8.

5. Orlic D, Hill JM, Arai AE. Stem cells for myocardial regeneration. Circ Res 2002;91:1092-102.

6. Menasche P. Skeletal muscle satellite cell transplantation. Cardiovasc Res 2003;58:351-7.

7. Ghostine S, Carrion C, Souza LC, Richard P, Bruneval P, Vilquin JT, et al. Long-term efficacy of myoblast transplantation on regional structure and function after myocardial infarction. Circulation 2002;106:I131-6.

8. Pagani FD, DerSimonian H, Zawadzka A, Wetzel K, Edge ASB, Jacoby DB, et al. Autologous skeletal myoblasts transplanted to ischemia-damaged myocardium in humans. J Am Coll Cardiol 2003;41:879-88.

9. Taylor DA, Atkins BZ, Hungspreugs P, Jones TR, Reedy MC, Hutcheson KA, et al. Regenerating functional myocardium: improved performance after skeletal myoblast transplantation. Nat Med 1998;4:929-33.

10. Pouzet B, Vilquin JT, Hagege AA, Scorsin M, Messas E, Fiszman M, et al. Factors affecting functional outcome after autologous skeletal myoblast transplantation [discussion, 850-1]. Ann Thorac Surg 2001;71:844-50.

11. Reinecke H, MacDonald GH, Hauschka SD, Murry CE. Electromechanical coupling between skeletal and cardiac muscle. Implications for infarct repair. J Cell Biol 2000;149:731-40.

12. Leobon B, Garcin I, Menasche P, Vilquin JT, Audinat E, Charpak $\mathrm{S}$. Myoblasts transplanted into rat infarcted myocardium are functionally isolated from their host. Proc Natl Acad Sci USA 2003;100:7808-11.

13. Reinecke H, Minami E, Poppa V, Murry CE. Evidence for fusion between cardiac and skeletal muscle cells. Circ Res 2004;94:e56-60.

14. Menasche P, Hagege AA, Scorsin M, Pouzet B, Desnos M, Duboc $\mathrm{D}$, et al. Myoblast transplantation for heart failure. Lancet 2001;357:279-80.

15. Menasche P, Hagege AA, Vilquin JT, Desnos M, Abergel E, Pouzet B, et al. Autologous skeletal myoblast transplantation for severe postinfarction left ventricular dysfunction. J Am Coll Cardiol 2003;41:1078-83.

16. Siminiak T, Fiszer D, Jerzykowska O, Grygielska B, Kalmucki P, Kurpisz M. Percutaneous autologous myoblast transplantation in the treatment of post-infarction myocardial contractility impairment—report on two cases. Kardiol Pol 2003;59:492-501.

17. Herreros J, Prosper F, Pérez A, Gavira JJ, García-Velloso MJ, Barba J, et al. Autologous intramyocardial injection of cultured skeletal muscle-derived stem cells in patients with non-acute myocardial infarction. Eur Heart J 2003;24:2012-20.

18. Smits PC, van Geuns RJ, Poldermans D, Bountioukos M, Onderwater $\mathrm{EE}$, Lee $\mathrm{CH}$, et al. Catheter-based intramyocardial injection of autologous skeletal myoblasts as a primary treatment of ischemic heart failure: clinical experience with six-month follow-up. J Am Coll Cardiol 2003;42:2063-9.

19. Hagege AA, Carrion C, Menasche P, Vilquin JT, Duboc D, Marolleau JP, et al. Viability and differentiation of autologous skeletal myoblast grafts in ischaemic cardiomyopathy. Lancet 2003; 361:491-2.

20. Allman KC, Shaw LJ, Hachamovitch R, Udelson JE. Myocardial viability testing and impact of revascularization on prognosis in patients with coronary artery disease and left ventricular dysfunction: a meta-analysis. J Am Coll Cardiol 2002;39:1151-8.

21. Zhang M, Methot D, Poppa V, Fujio Y, Walsh K, Murry CE. Cardiomyocyte grafting for cardiac repair: graft cell death and anti-death strategies. J Mol Cell Cardiol 2001;33:907-21.

22. Askari AT, Unzek S, Popovic ZB, Goldman CK, Forudi F, Kiedrowski M, et al. Effect of stromal-cell-derived factor 1 on stemcell homing and tissue regeneration in ischaemic cardiomyopathy. Lancet 2003;362:697-703.

23. Tomita S, Li RK, Weisel RD, Mickle DA, Kim EJ, Sakai T, et al. Autologous transplantation of bone marrow cells improves damaged heart function. Circulation 1999;100:II247-56.

24. Kamihata H, Matsubara H, Nishiue T, Fujiyama S, Tsutsumi Y, Ozono R, et al. Implantation of bone marrow mononuclear cells into ischemic myocardium enhances collateral perfusion and regional function via side supply of angioblasts, angiogenic ligands, and cytokines. Circulation 2001;104:1046-52.

25. Agbulut O, Menot ML, Li Z, Marotte F, Paulin D, Hagege AA, et al. Temporal patterns of bone marrow cell differentiation following transplantation in doxorubicin-induced cardiomyopathy. Cardiovasc Res 2003;58:451-9.

26. Bel A, Messas E, Agbulut O, Richard P, Samuel JL, Bruneval P, et al. Transplantation of autologous fresh bone marrow into infarcted myocardium: a word of caution. Circulation 2003;108(Suppl 1):II247-52.

27. Strauer BE, Brehm M, Zeus T, Kostering M, Hernandez A, Sorg $\mathrm{RV}$, et al. Repair of infarcted myocardium by autologous intracoronary mononuclear bone marrow cell transplantation in humans. Circulation 2002;106:1913-8.

28. Kang HJ, Kim HS, Zhang SY, Park KW, Cho HJ, Koo BK, et al. Effects of intracoronary infusion of peripheral blood stem-cells mobilised with granulocyte-colony stimulating factor on left ventricular systolic function and restenosis after coronary stenting in myocardial infarction: the MAGIC cell randomised clinical trial. Lancet 2004;363:751-6.

29. Avilés FF, San Román JA, García Frade J, Valdés M, Sánchez A, De la Fuente L, et al. Regeneración miocárdica mediante la implantación intracoronaria de células madre en el infarto agudo de miocardio. Rev Esp Cardiol 2004;57:201-8.

30. Perin EC, Dohmann HF, Borojevic R, Silva SA, Sousa AL, Mesquita CT, et al. Transendocardial, autologous bone marrow cell transplantation for severe, chronic ischemic heart failure. Circulation 2003; 107:2294-302.

31. Tse HF, Kwong YL, Chan JK, Lo G, Ho CL, Lau CP. Angiogenesis in ischaemic myocardium by intramyocardial autologous bone marrow mononuclear cell implantation. Lancet 2003;361:47-9.

32. Fuchs S, Satler LF, Kornowski R, Okubagzi P, Weisz G, Baffour $\mathrm{R}$, et al. Catheter-based autologous bone marrow myocardial injection in no-option patients with advanced coronary artery disease: a feasibility study. J Am Coll Cardiol 2003;41:1721-4.

33. Jackson KA, Majka SM, Wang H, Pocius J, Hartley CJ, Majesky MW, et al. Regeneration of ischemic cardiac muscle and vascular endothelium by adult stem cells. J Clin Invest 2001;107:1395402.

34. Kocher AA, Schuster MD, Szabolcs MJ, Takuma S, Burkhoff D, Wang J, et al. Neovascularization of ischemic myocardium by human bone-marrow-derived angioblasts prevents cardiomyocyte apoptosis, reduces remodeling and improves cardiac function. Nat Med 2001;7:430-6.

35. Orlic D, Kajstura J, Chimenti S, Jakoniuk I, Anderson SM, Li B, et al. Bone marrow cells regenerate infarcted myocardium. Nature 2001;410:701-5

36. Balsam LB, Wagers AJ, Christensen JL, Kofidis T, Weissman IL, Robbins RC. Haematopoietic stem cells adopt mature haematopoietic fates in ischaemic myocardium. Nature 2004;428:668-73.

37. Murry CE, Soonpaa MH, Reinecke H, Nakajima H, Nakajima HO, Rubart M, et al. Haematopoietic stem cells do not transdifferentiate into cardiac myocytes in myocardial infarcts. Nature 2004;428:664-8

38. Nygren JM, Jovinge S, Breitbach M, Sawen P, Roll W, Hescheler $\mathrm{J}$, et al. Bone marrow-derived hematopoietic cells generate cardiomyocytes at a low frequency through cell fusion, but not transdifferentiation. Nat Med 2004;10:494-501.

39. Álvarez-Dolado M, Pardal R, García-Verdugo JM, Fike JR, Lee $\mathrm{HO}$, Pfeffer K, et al. Fusion of bone-marrow-derived cells with Purkinje neurons, cardiomyocytes and hepatocytes. Nature 2003; 425:968-73.

40. Assmus B, Schachinger V, Teupe C, Britten M, Lehmann R, Dobert N, et al. Transplantation of Progenitor Cells And Regeneration Enhancement in Acute Myocardial Infarction (TOPCAREAMI). Circulation 2002;106:3009-17.

41. Stamm C, Westphal B, Kleine HD, Petzsch M, Kittner C, Klinge $\mathrm{H}$, et al. Autologous bone-marrow stem-cell transplantation for myocardial regeneration. Lancet 2003;361:45-6. 
42. Planat-Benard V, Silvestre JS, Cousin B, Andre M, Nibbelink M, Tamarat R, et al. Plasticity of human adipose lineage cells toward endothelial cells: physiological and therapeutic perspectives. Circulation 2004; 109:656-63

43. Planat-Benard V, Menard C, Andre M, Puceat M, Perez A, García-Verdugo JM, et al. Spontaneous cardiomyocyte differentiation from adipose tissue stroma cells. Circ Res 2004;94:223-9.

44. Makino S, Fukuda K, Miyoshi S, Konishi F, Kodama H, Pan J, et al. Cardiomyocytes can be generated from marrow stromal cells in vitro. J Clin Invest 1999;103:697-705.

45. Shake JG, Gruber PJ, Baumgartner WA, Senechal G, Meyers J, Redmond JM, et al. Mesenchymal stem cell implantation in a swine myocardial infarct model: engraftment and functional effects [discussion, 1926]. Ann Thorac Surg 2002;73:1919-25.
46. Toma C, Pittenger MF, Cahill KS, Byrne BJ, Kessler PD. Human mesenchymal stem cells differentiate to a cardiomyocyte phenotype in the adult murine heart. Circulation 2002;105: 93-8.

47. Mangi AA, Noiseux N, Kong D, He H, Rezvani M, Ingwall JS, et al. Mesenchymal stem cells modified with Akt prevent remodeling and restore performance of infarcted hearts. Nat Med 2003;9:1195-201.

48. Raff M. Adult stem cell plasticity: fact or artifact? Annu Rev Cell Dev Biol 2003;19:1-22.

49. Wagers AJ, Weissman IL. Plasticity of adult stem cells. Cell 2004;116:639-48.

50. Couzin J, Vogel G. Cell therapy. Renovating the heart. Science 2004;304:192-4. 